\title{
FABRICATION OF MECHANICAL DEVICE FOR LIFTING CHILD FROM BORE-WELL
}

\author{
Bivek Bhattarai ${ }^{1}$, Boris Gharti Chhetri ${ }^{2}$, Chandan Kumar Singh ${ }^{3}$, Kalimullah Miya ${ }^{4}$ \\ ${ }^{1,2,3,4}$ B.E. Students, Department of Mechanical Engineering, Sri Venkateshwara College of Engineering, VTU, \\ Bangalore-562 157, India
}

\begin{abstract}
As we are seeing from many years children have been falling into bore-well which was dug to fetch water but left as it is when not getting water. The bore-well owner/digger don't take any safety precaution for covering those bore-wells. Rescuing children from such situation is not an easy task as it takes hours of time and human effort to do so. There are several incidents of children falling into bore-wells in the recent past. And their parents started to search for rescue services. Today, with the help of technology we develop lot of instruments/devices which consists of sensors, actuators, mechanisms to save the children. But this technology can be adopted by the person one who knows the operation? How it works? This technology is not suitable for the village areas where most people are unknown to new technologies. So, our aim is to construct a simple and easily operable mechanical device to lift a child from the bore-well. We use high definition camera to visualize child condition from PC and operate mechanical graspers to grasp the child. Then, by the help of automated lifting system, the child is rescued from bore-well. For automation, light weight geared motors are used which give slow speed but greater torque which is run by DC battery and are controlled by toggle switches.
\end{abstract}

Keywords: Leds, HD Camera, Gripper, Geared Motor, Toggle Switches.

\section{INTRODUCTION}

At present context, clean water scarcities are leading for construction of underground bore-wells to get water. And the number of bore-wells are increasing day by day. If there is no availability of water in the bore-well then it is left as it is by the constructors in most cases, which is the reason why those life taking bore-wells exist. In other cases, children unaware of such bores, and children playing carelessly around such uncovered bore-wells become its victim.

There is no proper equipment available for handling rescue operation. Usually, conventional method i.e., parallel digging is used to rescue the child from bore-wells. It takes a lot of time and resources to perform such operation. In most cases, the child is found dead, because of long operation time and falling of foreign materials on the child which harms the child breathing.

In the world of technological advancement, we can ease our work by creating machines and equipment according to our requirement. Man has created from simple machines such as lever, pulley to complex robots and spacecraft. As we can find variety of materials and components in the market to create our own machine, why not create a rescuing device that can lift a trapped child out of bore-well. So we have built a device that is simple in making, easily operable and takes less energy for operation. The benefits we can get from this device are: it is able to rescue trapped child in short period of time, it can be used to detect the leakages in pipes, and also it can be used to clean the inner parts of pipes or remove the blockage created by foreign materials. Moreover, it can be used in any sort of bore-wells; deserted or with casings.
We have designed a light weight device so that it can be transported from one place to another easily due to the fact that there may be trapped victims at different locations at different time. This device can overcome the difficulties of adopting parallel digging, such as more time consumption, more rescue personnel, and yet very less chance of success in saving child's life.

\section{LITERATURE SURVEY}

S. Gopinath et-al ${ }^{[1]}$ - describes the system used for rescue child from bore-well. This system consists of ZigBee technology for data transferring between victim in bore-well and recovery team in earth surface, vacuum cup is used to adjust the child position, the arm movement of robot is controlled by stepper-motor, BLDC motor is used to lift the child from bore-well, camera along with LED light is used to visualize the victim and operated by control unit and finally simulation result is obtained by using the software Keil C.

K. Mohan Kumar et-al ${ }^{[2]}$ - describes the construction and design of multi-fingered robot for rescue purpose from the bore-well. It is operated using wireless, it includes temperature sensor for measuring the temperature inside the bore-well, heartbeat monitoring sensor is used for monitoring the heartbeat ratio of the baby, Tactile Sensor is used for providing touch sensor to the hand, oxygen supply unit is used for providing sufficient amount of oxygen to the baby and LED light is used for light source inside the borewell. 
G. Nithin et-al ${ }^{[3]}$ - describes the rescue operation which consists of three processes; approaching the child, handling the body, taking child out of the bore-well. A regular autonomous robot would easily perform the first and third operation, but by doing second operation it hurts the child, so the aim of this project is extreme safe handling of the child. The design of handling system is made in such a way that the child never gets hurt and the robot itself provide some pre-treatment to make the child survive till the end of the operation, it constitutes a best ergonomic design and performs safest rescue operation.

\section{LIST OF CHILDREN STRUCK IN BORE- WELL}

Table I: Incidents recorded between 2011-2016

\begin{tabular}{|c|c|c|c|c|c|}
\hline $\begin{array}{c}\text { SL. } \\
\text { NO. }\end{array}$ & NAME OF CHILD & AGE & PLACE OF INCIDENT & $\begin{array}{c}\text { ALIVE OR } \\
\text { DEAD }\end{array}$ & $\begin{array}{c}\text { SOURCE OF } \\
\text { INFORMATION }\end{array}$ \\
\hline 1 & SHANVI & 2 & $\begin{array}{c}\text { DHIPATUNKA VILLAGE, NALGONDA } \\
\text { ZONE }\end{array}$ & NOT ALIVE & NDTV(02-02-2016) \\
\hline 2 & RAGHAV & 3 & $\begin{array}{c}\text { NAND GANGOLI VILLAGE, MADHYA } \\
\text { PRADESH }\end{array}$ & NOT ALIVE & NDTV(20-10-2015) \\
\hline 3 & ANIL & 3 & $\begin{array}{c}\text { HANUMANGARH DISTRICT, } \\
\text { RAJASTHAN }\end{array}$ & NOT ALIVE & NDTV(08-10-2015) \\
\hline 4 & JYOTI & 2.5 & DAUSA DISTRICT, RAJASTHAN & ALIVE & NDTV(05-10-2015) \\
\hline 5 & BABITA & 5 & $\begin{array}{c}\text { MITRA MANDAL COLONY,PATNA, } \\
\text { BIHAR }\end{array}$ & $\begin{array}{c}\text { DIED IN } \\
\text { HOSPITAL }\end{array}$ & NDTV(29-06-2015) \\
\hline 6 & THAMIZHARASAN & 2.5 & $\begin{array}{c}\text { KOORAMPADI VILLAGE, ARCOT } \\
\text { TALUK, VELLORE,TAMILNADU }\end{array}$ & $\begin{array}{c}\text { NOT ALIVE } \\
\text { NDTV(12-04-2015) }\end{array}$ \\
\hline 7 & R. MADHUMITHA & 3 & $\begin{array}{c}\text { VILLUPURAM } \\
\text { DISTRICT,TAMILNADU }\end{array}$ & $\begin{array}{c}\text { RECOVERED } \\
\text { ALIVE }\end{array}$ & $\begin{array}{c}\text { THE TIMES OF } \\
\text { INDIA(5-4-2014) }\end{array}$ \\
\hline 8 & RADHESHYAM & 2.5 & CHURA DISTRICT,JAIPUR & $\begin{array}{c}\text { DIED IN } \\
\text { HOSPITAL }\end{array}$ & $\begin{array}{c}\text { THE TIMES OF } \\
\text { INDIA(7-1-2014) }\end{array}$ \\
\hline 9 & CHOTU & 9 & KARAULI DISTRICT,RAJASTHAN & NOT ALIVE & IBN LIVE(10-8-2013) \\
\hline 10 & TANU & 4 & PALWAL, HARAYANA & ALIVE & IBN LIVE(30-5-2013) \\
\hline 11 & MUTHULAKSHMI & 7 & $\begin{array}{c}\text { SURYPALLI, } \\
\text { VILLAGES,TAMILNADU }\end{array}$ & $\begin{array}{c}\text { HOSPITAL } \\
\text { IBN LIVE(28-4-2013) }\end{array}$ \\
\hline
\end{tabular}

\section{FABRICATION OF THE DEVICE}

In order to build up our device, we used the following components:

\section{A. Frame}

It consists of base, a Pipe, the supports for pipe as well as pulley, and a rotating handle. The base is made up of wood on which the whole pipe and arm system are mounted. The pipe is made up of polyvinyl chloride (PVC). The support is made from mild steel which holds the pipe up right and also it carries a pulley at its top part with the help of hook. A rotating handle with hollow shaft, is welded to the support which is also made up of mild steel. The hollow shaft is free to rotate due to the bearing provide at its end.

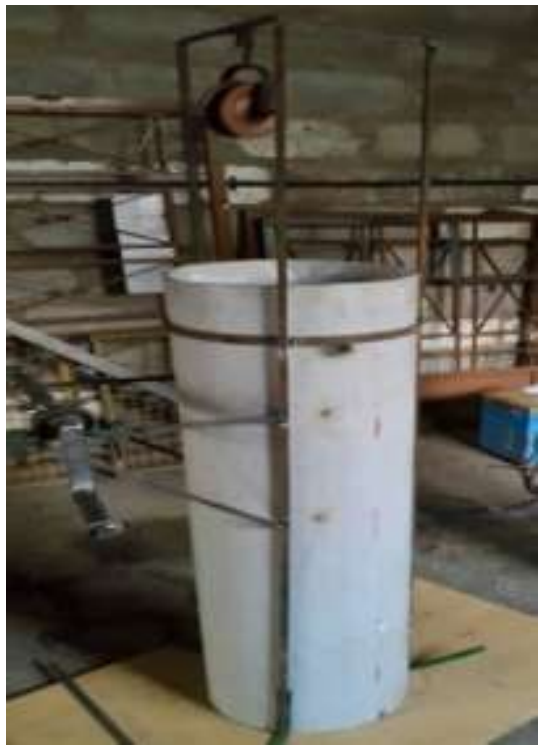

Fig.1 Bore-well rescue device 


\section{B. Lifting Elements}

The lifting elements consist of rope, pulley and automated rope winding shaft. The material of rope is Nylon and that of pulley is Plastic. There are lot of lifting elements available in the market but they have their own limitations. For example, we could have used chain and sprocket or gear drive as lifting element. But the main problem of chain and sprocket and gear drive is that they are fixed drives. Whereas, rope is flexible enough to be used in short depth as well as long depth as they can be wounded around for lifting and releasing. Moreover, rope is quiet lighter in weight and smaller in cross section than other lifting elements which is very advantageous in our project where size and weight are two major factors. The pulley is made up of plastic which is used to support movement and change of direction of a rope along its circumference.

\section{Grasper}

The grasper system consists of two links; one fixed and another movable, geared motors. The geared motors actuate the movable links in order to grasp the child. The material for these links are mild steel.

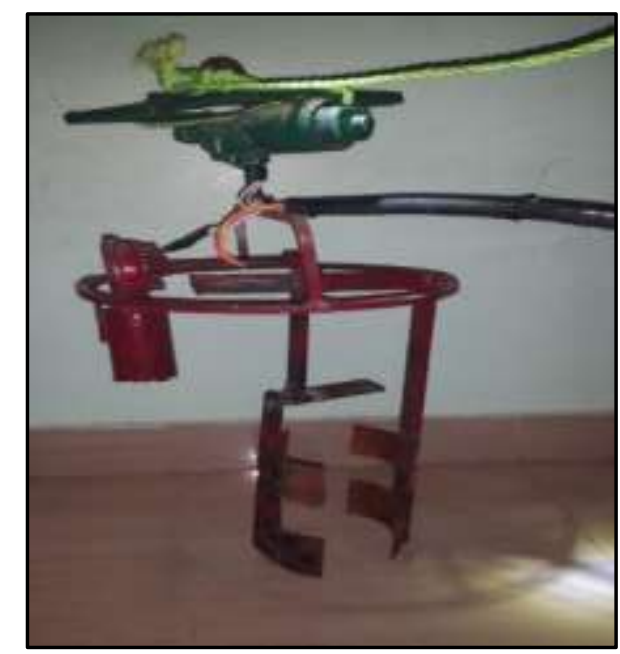

Fig.2 Grasper

\section{Control System}

The control system consists of Toggle switch, Battery, Camera, LED, and wires. The toggle switch is used to control the operation of grasper by precise rotation of motor. The battery is used for supplying power to the motor, LEDs, and camera. The camera is used to visualize the child inside bore-well by illuminating the surrounding with the help of LEDs. All these components are connected using wires.

\section{E. Oxygen Supply Unit}

Oxygen is the fundamental need of life. The rescue operation may take several hours for extraction of the child. If the child lacks oxygen in the bore-well, he may suffer from hyperthermia and we might fail in saving his/her life. Thus, an oxygen supply unit is a most in order to provide adequate amount of oxygen to the child. It consists of oxygen cylinder, concentrator, pressure gauge and hose.

\section{F. Audio System}

An audio system which comprise of microphone and speaker is attached to camera, so that it allows the operators at surface to hear the voice or movement of child and predict his/her condition of survival. It can also facilitate the child to communicate to his/her parents.

\section{OBJECTIVE}

The key objectives of the rescue device are:

a. To rescue the child from borehole in minimum amount of time.

b. To reduce human efforts and other resources.

c. To make simple construction and easily operable.

d. To suit all sort of bore-wells.

\section{METHODOLOGY}

The rescue operation is carried out in following sequences:

\section{A. Visualize the child}

When we lower the arm mechanism inside the bore-well, we can determine the depth of the bore-well by noticing the length of rope being drawn. We can see the child in the bore-well with the help of LEDs and camera provided with the arm.

\section{B. Determine the health condition of child}

By the help of PIR sensor we can sense the movement of the child which allows us to know if he is conscious or not. We will provide the oxygen gas at child place through hoses with pressure regulation.

\section{Grasp the child}

To grasp the child, we use an arm structure which is run by motor. The motor helps to reciprocate one of the link so that it close the gap and come in contact with the child. With the help of monitor visuals and the arm is precisely fixed at child's body such that it does not hurt the child while lifting.

\section{Pull Out}

The lifting of the child is done by rolling back the rope with the help of rotational handle outside the bore-well.

\section{APPLICATIONS}

The main focus of our project is to rescue the child out of bore-well. But our project can serve various other purposes as given below:

\section{A. Pick and Place}

It can be used to lift medium weights for domestic as well as industrial purposes. Further, it can be improved to lift heavy loads and work in more depths. 


\section{B. Clean Pipes}

It can be used to clean long pipes of diameter as that of bore-wells or even greater by providing brushes at the arm ends.

\section{Inspect Water or Oil Pipes}

It can be used to check the cracks and holes in pipes and determine the harm they may cause. The leakages can be sealed by squeezing the sealants at required locations.

\section{RESULTS AND CONCLUSION}

The device was tested for its ability to grasp and lift the dummy of a child. It did its job with smooth operation and precise control. The geared motor was best suited to the lifting arms as well as gripper arms. The curved surface of the grippers allowed more area for grasping the dummy and also helped to distribute the applied pressure uniformly in the body of the dummy rather than concentrating at one body part.

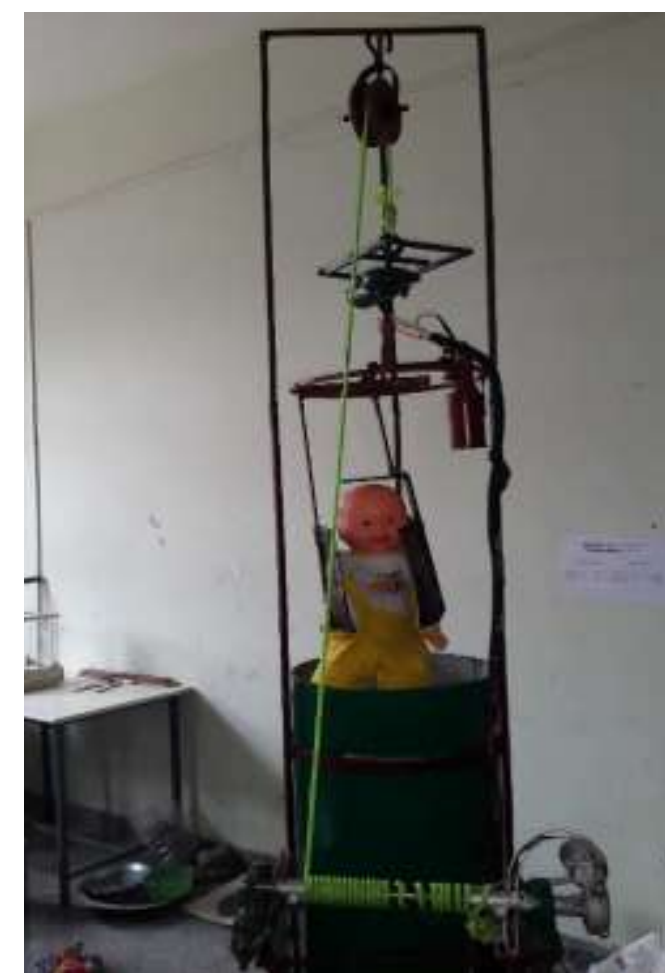

Fig.3 Safe rescue of dummy child

\section{REFERENCES}

[1] Bharathi and al. "Design and Construction of Rescue Robot and Pipeline Inspection Using ZigBee" www.ijser.inISSN (Online): 2347-3878 Volume 1 Issue 1, September 2013

[2] Palwinder Kaur and al. "PIPELINE INSPECTION AND bore-well RESCUE ROBOT" Volume: 03 Issue: 04 | Apr-2014, eISSN: 2319-1163 | pISSN: 2321-7308

[3] Palwinder Kaur and al. "Hardware and Software Implementation of A Robot for Bore-Well Rescue Operations" www.ijetae.com (ISSN 2250-2459, ISO
9001:2008 Certified Journal, Volume 4, Issue 8, August 2014) 645

[4] Shah Vrunda R and al. AUTOMATE MACHINE FOR RESCUE OPERATION FOR CHILD”, EISSN: 23191163 | pISSN: 2321-7308, Volume: 04 Issue: 02 | Feb2015

[5] Venmathi and al. " bore-well Rescue Robot" International Journal of Computer Applications (0975 8887) Volume 113 - No. 14, March 2015

[6] K. Mohan Kumar and al." Design of Multi fingered Rescue Hand Robot with Teleportation, ISSN(Online) : 2319 - 8753, Vol. 4, Special Issue 6, May 2015

[7] Navya and al. "RESCUE DEVICE FOR LIFTING INFANTS STRUCK IN PITS" Proceedings of 12th IRF International Conference, Bengaluru, India, 17th May 2015, ISBN: 978-93-85465-13-0

[8] S. Gopinath and al. " Rescue Child from Bore well using Embedded System” e-ISSN: 2395 -0056 , pISSN: 2395-0072 Volume: 02 Issue: 03 | June-2015, www.irjet.net

[9] K. Saran and al. "BORE-WELL RESCUE ROBOT" ISSN (ONLINE): 2321-3051

[10] Satya Prasad Tadavarthy and al. "Borehole Robot for Rescue of a Child" ISSN 2320-088X, IJCSMC, Vol. 3, Issue. 11, November 2014, pg.183 - 193 